\title{
Importance of Integrating SDGs Into Business Process by Telecommunication Operators: Opinion of Estonian Customers
}

EIS 15/2021

Importance of Integrating SDGs Into Business Process by Telecommunication Operators: Opinion of Estonian Customers

Submitted 03/2021

Accepted for publication $06 / 2021$
Natalie Aleksandra Gurvitš-Suits

Tallinn University of Technology

\section{Anna-Liiza Lvova}

Tallinn University of Technology

$\Gamma$ Crossef http://dx.doi.org/10.5755/j01.eis.1.15.28779
Sustainable development is recognized by the United Nations as a challenge for social and economic policy Hughes\&Johnston (2005), an urgent call for action by all countries addressing all groups of stakeholders (Mio et al., 2020) and one of the main priorities for business community all over the world (Tsalis et al., 2020). Successful implementation and achievement of these goals should be a result of joint efforts of all countries and nations. And while a general success is observed in case of certain SDGs, others still require joint efforts and cooperation on both national and international level. A vital role is assigned to businesses which can also contribute to achievement of SDGs by integrating them into everyday processes.

Purpose: The aim of the research was to reveal the customers opinion on the importance of embedding SDGs by businesses into everyday process in Estonia.

The telecommunication operating companies were chosen due to their central role in the modern business world and huge impact on nearly every aspect of society. There was conducted a survey in a form of questionnaire among customers of these companies and 512 responses were collected in a period of September 2020 -February 2021.

Results of the study demonstrate stakeholders concern on the achievement of the SDGs and revealed that the embedding of several SDGs: number 3 (good health and well-being), 4 (quality education), 6 (clean water and sanitation), 12 (responsible consumption and production), 15 (life on land) into business process is considered by customers to be the of the highest priority. Authors believe that the study with its findings intends to benefit SDG implementation by business companies in Estonia and provides a pattern for further developments of sustainable policies and strategies. This work provides one of the first studies in Estonia contributing towards understanding of whether businesses are supposed to embed the SDGs into their activities as seen by customers.

KEYWORDS: Agenda 2030, Sustainable development, SDG, telecommunication industry, implementation.

Sustainable development is recognized by the United Nations as a challenge for social and economic policy Hughes\&Johnston (2005), an urgent call for action by all countries addressing all groups of stakeholders (Mio et al., 2020), and one of the main priorities for business community all over the world (Tsalis et al., 2020). As a result of stakeholders' deep concern and active involvement the sustainable development goals were formulated intending to change and foster the implementation of sustainable development Allen et.al (2017) and addressing main important issues like peacekeeping, protecting human rights, reducing inequalities etc. as presented in Table 1. (United Nations, 2021).

\section{Abstract}

Introduction and literature review

\section{ktu \\ 1922}

European Integration Studies No. 15 / 2021, pp. 221-230 doi.org/10.5755/j01.eis.1.15.28779 
Table 1

Diversity dimensions

Source: Authors' basis 17 Goals by the United Nations

\begin{tabular}{|c|c|c|}
\hline $\begin{array}{l}\text { Goal } \\
\text { No. }\end{array}$ & SDG & More information on the goal \\
\hline 1 & No Poverty & End poverty in all its forms everywhere \\
\hline 2 & Zero Hunger & $\begin{array}{l}\text { End hunger, achieve food security and improved nutrition and } \\
\text { promote sustainable agriculture }\end{array}$ \\
\hline 3 & Good Health and Well-being & Ensure healthy lives and promote well-being for all at all ages \\
\hline 4 & Quality Education & $\begin{array}{l}\text { Ensure inclusive and equitable quality education and promote } \\
\text { lifelong learning opportunities for all }\end{array}$ \\
\hline 5 & Gender Equality & Achieve gender equality and empower all women and girls \\
\hline 6 & Clean Water and Sanitation & $\begin{array}{l}\text { Ensure availability and sustainable management of water and } \\
\text { sanitation for all }\end{array}$ \\
\hline 7 & $\begin{array}{l}\text { Affordable and Clean } \\
\text { Energy }\end{array}$ & $\begin{array}{l}\text { Ensure access to affordable, reliable, sustainable and modern energy } \\
\text { for all }\end{array}$ \\
\hline 8 & $\begin{array}{l}\text { Decent Work and } \\
\text { Economic Growth }\end{array}$ & $\begin{array}{l}\text { Promote sustained, inclusive and sustainable economic growth, full } \\
\text { and productive employment and decent work for all }\end{array}$ \\
\hline 9 & $\begin{array}{l}\text { Industry, Innovation and } \\
\text { Infrastructure }\end{array}$ & $\begin{array}{l}\text { Build resilient infrastructure, promote inclusive and sustainable } \\
\text { industrialization and foster innovation }\end{array}$ \\
\hline 10 & Reduced Inequality & Reduce inequality within and among countries \\
\hline 11 & $\begin{array}{l}\text { Sustainable Cities and } \\
\text { Communities }\end{array}$ & $\begin{array}{l}\text { Make cities and human settlements inclusive, safe, resilient and } \\
\text { sustainable }\end{array}$ \\
\hline 12 & $\begin{array}{l}\text { Responsible Consumption } \\
\text { and Production }\end{array}$ & Ensure sustainable consumption and production patterns \\
\hline 13 & Climate Action & Take urgent action to combat climate change and its impacts \\
\hline 14 & Life Below Water & $\begin{array}{l}\text { Conserve and sustainably use the oceans, seas and marine } \\
\text { resources for sustainable development }\end{array}$ \\
\hline 15 & Life on Land & $\begin{array}{l}\text { Protect, restore and promote sustainable use of terrestrial } \\
\text { ecosystems, sustainably manage forests, combat desertification, } \\
\text { and halt and reverse land degradation and halt biodiversity loss }\end{array}$ \\
\hline 16 & $\begin{array}{l}\text { Peace and Justice } \\
\text { Strong Institutions }\end{array}$ & $\begin{array}{l}\text { Promote peaceful and inclusive societies for sustainable } \\
\text { development, provide access to justice for all and build effective, } \\
\text { accountable and inclusive institutions at all levels }\end{array}$ \\
\hline 17 & $\begin{array}{l}\text { Partnerships to } \\
\text { achieve the Goal }\end{array}$ & $\begin{array}{l}\text { Strengthen the means of implementation and revitalize the global } \\
\text { partnership for sustainable development }\end{array}$ \\
\hline
\end{tabular}

The latest document "The 2030 Agenda for Sustainable Development" emphasizes a "world free of poverty, hunger, disease and want ... free of fear and violence ... with equitable and universal access to quality education, health care and social protection ... to safe drinking water and sanitation ... where food is sufficient, safe, affordable and nutritious ... where habits are safe, resilient and sustainable ... and where there is universal access to affordable, reliable and sustainable energy." (United Nations, 2021). This document also requires changes in global mentality to implement the SDGs (Tremblay et.al, 2020) and achieve a collective success. Successful implementation and achievement of these goals should be a result of joint efforts of all countries on all levels and is challenging not only the countries to achieve these goals but also "the evaluation practice 
of multinational and national organizations" (Meyer, 2020). It would also have a vital impact on the well-being on society and planet (Silva, 2021). Biermann et al. ,2017 believes that these goals have a great potential, however their success depends on various institutional factors such as "the extent to which states formalize their commitments, strengthen related global governance arrangements, translate the global ambitions into national contexts, integrate sectoral policies, and maintain flexibility in governance mechanisms." (Biermann et al. ,2017). However, there is a raising concern there whether SDGs address real problems of nations, particularly the developing world (Khalid et.al, 2020). According to Kroll et.al. (2019) there is observed a positive development for certain goals, while in case of sustainable consumption and nature there is a need "to foster innovations and policies that can make our cities and communities more sustainable, as well as strengthen institutions and spur climate action" (Kroll et.al., 2019). The reason maybe the complexity of goals and diversity among countries, insufficient understanding and addressing of interactions between the formulated goals and related targets (Breu et.al, 2021). This is also confirmed by studies of Zhang et al. (2019) claiming that while according to Agenda 2030 the SDGs are universal and applicable in every country it gives no details on interaction on these goals thus making their implementation more complicated.

Numerous studies have investigated the interactions between sustainable development goals (Kunčič, 2019, Ramos\&Laurenti, 2020; Scharlemann, 2020; Breu et.al., 2021) aiming to contribute to their successful achievement. Warchold et.al (2020) conducted a research for the year 2016 to understand SDGs and suggests that synergies should outweigh the trade-offs and it is important to address all inequalities among countries with no exceptions.

Numerous studies analyse performance of countries in their progress towards SDGs achievement and successful implementation outlining the ones attracting most attention and revealing difference in implementation: Allen et.al (2020) explored the progress of SDG implementation in Australia and their results reveal the mixed performance on the SDGs, with strong progress in goals relating to health and education and poor progress in goals relating to climate action and reducing inequalities. Findings of Xie et.al (2021) revealed that South Korea considers ecological sustainability a matter of high importance while social sustainability dimensions are mostly addressed in China and Japan. It should be noted that Estonia has been successful in implementation of SDGs and in 2019 it appeared to be the tenth in the global Sustainable Development Report with achieving a distinguished progress in quality education, effective healthcare organization, high employment rate with minimal long-term unemployment, and a high proportion of renewable energy in overall energy consumption. (Sustainable Development Goals Knowledge..., 2020). While several SDGs like gender equality, reducing risk of poverty achieved less progress and still need to be actively targeted (Sustainable Development Goals Knowledge..., 2020) These gaps could be overcome by the contribution of the business companies to the fulfilment of SDGs by embedding them into business strategies. This is also the matter of growing attention and raising concern among stakeholders as according to García-Sánchez et.al (2020) there is a growing interest from institutional investors related to the embedding of SDG into the business strategies of sustainable and responsible development. Santos\&Silva (2020) investigated the reasons and ways of incorporating the sustainable development goals (SDGs) into the strategies of large Portuguese companies. Their findings suggest that among different reasons there should be outlined "the understanding of the 2030 agenda as an ethical and social contract followed by concerns over managing stakeholders" by the selected companies.

Effectiveness of positive practices contributing to SDGs are shown by Google, Apple, Microsoft, Amazon and Facebook by providing their data centers with renewable energy Patchell\&Hayter (2021) and Caribbean tour operators designing new products and services implementing fair labor and operating practices. (Milwood, 2020). 
Different studies examined the SDGs implementation by various businesses: Avrampou et al. (2019) examined whether the reported performance of small leading European banks was in line with supporting the SDGs and their findings reported low level of contribution being diversified to individual SDG goals.

Cai\&Choi (2020) have investigated the possibilities of textile and apparel supply chains to comply with the SDGs. The results of the study confirmed that while some goals like "Responsible Consumption and Production", "Clean Water and Sanitation", and "Climate Action" receive a considerable amount of attention the other ones like "No Poverty", "Reduced Inequalities", "Life below Water" and "Life on Land" gained least attention. They also noted that the stakeholders' initiatives could have a strong impact on the focus and actions of companies. (Cai\&Choi, 2020)

Kandler Rodríguez (2020) investigated which SDGs are most mentioned in the sustainability programs of two hospitality companies of Costa Rica and stated that most closely these programs would support the achievement of the following SDGs: Sustainable Cities and Communities, Responsible Consumption and Production, Climate Action.

The literature overview enables to conclude that companies are shifting their focus towards the SDGs implementation into their strategies and examples of positive contribution in different countries are numerous and impressive. The main motivators are ethical and social responsibility as well as raising concern among stakeholders. However, little is known about the opinion of Estonian stakeholders on this matter. Therefore, authors decided to fill this gap by the present study aiming to determine the opinion of Estonian respondents on the importance of embedding SDGs by businesses into everyday processes. Hence, the telecommunication operating companies were chosen due to their growing impact on every aspect of society and important role in everyday life. Almost all Estonian people use their services being well aware of their activities and visit websites of these companies quite often. The main aim of this research is to reveal the customers opinion on the importance of embedding SDGs by businesses into everyday process in Estonia.

Therefore, authors have set the task to arrange a survey among the customers of these companies in order to find out their opinion on the importance of embedding SDGs by businesses into everyday process in Estonia. The study with its findings intends to benefit SDG implementation by business companies in Estonia. This study also provides one of the first in Estonia contributing towards understanding of whether businesses are supposed to embed the SDGs into their activities as seen by customers.

The authors conducted a survey, which consisted of questions related to the importance of incorporation of the SDG by the business companies: opinion of customers. The languages of the questionnaire were Estonian and Russian. To present the questions and make it possible to collect data, an online survey engine Google Forms was used, authors also distributed questionnaires personally to respondents via email or in a paper form. The survey included three single choice questions, where respondents were asked about their awareness of social responsibility, whether it adds value to the image of the company and the importance of disclosing information on sustainable development of companies. The main part consisted of linear scale questions, where respondents were asked to rank each argument from 1 (strong disagreement) to 5 (total agreement) in order to express their agreement or disagreement with each statement. The arguments presented the SDG definition together with the full detailed explanation as provided in Table 1. This table in short is summarizing all the information about the SDGs and gives respondent a good overview of all goals. Estimated time for the survey completion was between 10 to 15 minutes. 
The survey was conducted among users of services provided by telecommunication company currently operating in Estonia. Pilot survey was organized prior to the survey period, which received positive feedback from respondents and therefore, the questionnaire was distributed in Estonia during the period of 22.09.2020-22.10.2020 with 230 responses received (this data was used by one of the authors in the master thesis) and 01.12.2020 - 01.02.2021 (282 responses were collected). In total 512 responses were collected and authors consider this data as a basis for new and independent research presented in this article. This information was compiled and analysed. Table 2 shows demographic data of the survey.

\begin{tabular}{|c|c|c|}
\hline Age of respondents & Number of respondents & Percentage of respondents \\
\hline 26 years and younger & 157 & $30,7 \%$ \\
\hline $27-50$ years & 321 & $62,7 \%$ \\
\hline 51 years and older & 34 & $6,6 \%$ \\
\hline Total: & 512 & $100 \%$ \\
\hline Education of respondents & Number of respondents & Percentage of respondents \\
\hline Bachelor & 227 & $44,3 \%$ \\
\hline Master & 184 & $35,9 \%$ \\
\hline $\mathrm{PhD}$ & 4 & $0,8 \%$ \\
\hline Other & 97 & $19 \%$ \\
\hline Total: & 512 & $100 \%$ \\
\hline Work experience of respondents & Number of respondents & Percentage of respondents \\
\hline$<1$ year & 34 & $6,6 \%$ \\
\hline $1-5$ years & 98 & $19,1 \%$ \\
\hline $6-10$ years & 115 & $22,5 \%$ \\
\hline $11-15$ years & 100 & $19,5 \%$ \\
\hline$>15$ years & 165 & $32,2 \%$ \\
\hline Total: & 512 & $100 \%$ \\
\hline
\end{tabular}

It should be noted that $95 \%$ of the respondents claimed to be aware of what social responsibility and associated benefits for the business entity. They also agreed with the statement that a company should provide information to stakeholders about its sustainable development. More than $80 \%$ of respondents also confirmed that socially responsible behaviour would add value to the reputation of the company.

The following tables represent the opinion of respondents on the importance of SDGs implementation into business practices of telecommunication operators. Authors have divided 17 SDGs into three groups "People, Planet and Society". Table 3 represents data for the "People" section

Data of the Table 3 reveals that in the opinion of respondents from "people-orientated" SDGs the most important ones the companies should contribute to is "quality education" (average score 4.02) and "good health and well-being" (average score 3.82). These results are in line with the data of Estonia's Voluntary National Review 2020. According to this review Estonia is generally successful in implementing the SDGs, with the main strengths: accessible and quality education, effective
Table 2

General data about respondentss

Source: Authors'. 
Table 3

Embedding SDGs into business processes by telecommunications companies operating in Estonia Group 1-People (rated by Likert scale,

1- not important at all; 5very important)

Source: Authors'.

\section{Table 4}

Embedding SDGs into business processes by telecommunications companies operating in Estonia Group 2- Planet (rated by Likert scale, 1- not important at all; 5very important)

Source: Authors'.

\begin{tabular}{|c|c|c|c|c|c|c|c|c|c|c|c|}
\hline SDG & & 1 & & 2 & & 3 & & 4 & & 5 & Average \\
\hline No poverty & 42 & $8,20 \%$ & 58 & $11,33 \%$ & 95 & $18,55 \%$ & 165 & $32,23 \%$ & 152 & $18,95 \%$ & 3,64 \\
\hline $\begin{array}{l}\text { Good health and } \\
\text { well-being }\end{array}$ & 28 & $5,47 \%$ & 46 & $8,98 \%$ & 85 & $16,60 \%$ & 186 & $36,33 \%$ & 167 & $32,62 \%$ & 3,82 \\
\hline Quality education & 27 & $5,27 \%$ & 35 & $6,84 \%$ & 56 & $10,94 \%$ & 177 & $34,57 \%$ & 217 & $42,38 \%$ & 4,02 \\
\hline Gender equality & 32 & $6,25 \%$ & 64 & $12,50 \%$ & 100 & $19,53 \%$ & 138 & $26,95 \%$ & 178 & $34,77 \%$ & 3,71 \\
\hline Zero hunger & 51 & $9,96 \%$ & 75 & $14,65 \%$ & 101 & $19,73 \%$ & 142 & $27,73 \%$ & 143 & $27,93 \%$ & 3,49 \\
\hline $\begin{array}{l}\text { Decent work and } \\
\text { economic growth }\end{array}$ & 42 & $8,20 \%$ & 55 & $10,74 \%$ & 99 & $19,34 \%$ & 197 & $38,48 \%$ & 119 & $23,24 \%$ & 3,58 \\
\hline $\begin{array}{l}\text { Reduced } \\
\text { inequalities }\end{array}$ & 55 & $10,74 \%$ & 31 & $6,05 \%$ & 133 & $25,98 \%$ & 126 & $24,61 \%$ & 167 & $32,62 \%$ & 3,62 \\
\hline
\end{tabular}

healthcare organisation, high employment rate with minimal long-term unemployment, and a high proportion of renewable energy in overall energy consumption. (Sustainable Development Goals Knowledge..., 2020) The results of the present research confirm the fact that Estonia works hard on achieving the abovementioned SDGs as this is expected and highly valued by its inhabitants. This also enables to conclude, that Estonian people are concerned with the implementation of the selected goals and consider business companies to make their contributions by implementing them into everyday business processes. The data of Estonia's Voluntary National Review 2020 also pointed out that several SDG areas still require improvement: "need to focus on establishing gender equality (although decreased, the wage gap still remains among the highest in Europe), decreasing the risk of poverty for women and disabled people, including families with disabled children, establishing effective waste management and recycling, decreasing greenhouse emissions, and maintaining natural diversity" (Sustainable Development Goals Knowledge..., 2020) These findings are confirmed by the data presented in Table 4 related to the "Planet" section..

\begin{tabular}{|c|c|c|c|c|c|c|c|c|c|c|c|}
\hline SDG & & 1 & & 2 & & 3 & & 4 & & 5 & Average \\
\hline $\begin{array}{l}\text { Clean water and } \\
\text { sanitation }\end{array}$ & 23 & $4,49 \%$ & 27 & $5,27 \%$ & 59 & $11,52 \%$ & 157 & $30,66 \%$ & 246 & $48,05 \%$ & 4,13 \\
\hline $\begin{array}{l}\text { Affordable and } \\
\text { clean energy }\end{array}$ & 25 & $4,88 \%$ & 37 & $7,23 \%$ & 64 & $12,50 \%$ & 154 & $30,08 \%$ & 232 & $45,31 \%$ & 4,04 \\
\hline Climate action & 31 & $6,05 \%$ & 44 & $8,59 \%$ & 116 & $22,66 \%$ & 127 & $24,80 \%$ & 194 & $37,89 \%$ & 3,80 \\
\hline $\begin{array}{l}\text { Life below } \\
\text { water }\end{array}$ & 21 & $4,10 \%$ & 37 & $7,23 \%$ & 92 & $17,97 \%$ & 164 & $32,03 \%$ & 198 & $38,67 \%$ & 3,94 \\
\hline Life on land & 19 & $3,71 \%$ & 27 & $5,27 \%$ & 67 & $13,09 \%$ & 148 & $28,91 \%$ & 251 & $49,02 \%$ & 4,14 \\
\hline
\end{tabular}

Data of the Table 4 reveals that in the opinion of respondents from "society-orientated" SDGs the businesses should embed in their activities the SDGs aiming to provide "clean water and sanitation" (average score 4.13), which is in line with the results of research performed by Cai\&Choi (2020) while the "Climate Action" (average score 3.80) received least attention, contradicting their results. In authors opinion such controversial results are highly influenced by COVID-19. As 
disease outbreak outlined the importance of health measures helping to prevent getting infected (UNICEF, 2020) and also happened to have some positive effects on wildlife (Bates et al., 2020). Manenti et al., 2020).

Table 5 represents the data for the "Society" section.

\begin{tabular}{l|l|l|l|l|l|l|l|l|l|l|l|l|}
\multicolumn{1}{c|}{ SDG } & \multicolumn{2}{|c|}{1} & \multicolumn{2}{|c|}{2} & \multicolumn{2}{|c|}{3} & \multicolumn{2}{c|}{$\begin{array}{c}\text { Average } \\
\text { score }\end{array}$} \\
\hline $\begin{array}{l}\text { Industry, } \\
\text { innovation and } \\
\text { infrastructure }\end{array}$ & 38 & $7,42 \%$ & 52 & $10,16 \%$ & 75 & $14,65 \%$ & 154 & $30,08 \%$ & 193 & $37,70 \%$ & 3,80 \\
\hline $\begin{array}{l}\text { Sustainable } \\
\text { cities and } \\
\text { communities }\end{array}$ & 25 & $4,88 \%$ & 45 & $8,79 \%$ & 127 & $24,80 \%$ & 145 & $28,32 \%$ & 170 & $33,20 \%$ & 3,76 \\
\hline $\begin{array}{l}\text { Responsible } \\
\text { consumption and } \\
\text { production }\end{array}$ & 13 & $2,54 \%$ & 18 & $3,52 \%$ & 62 & $12,11 \%$ & 162 & $31,64 \%$ & 257 & $50,20 \%$ & 4,23 \\
\hline $\begin{array}{l}\text { Peace, justice } \\
\text { and strong } \\
\text { institutions }\end{array}$ & 42 & $8,20 \%$ & 55 & $10,74 \%$ & 135 & $26,37 \%$ & 109 & $21,29 \%$ & 171 & $33,40 \%$ & 3,61 \\
\hline $\begin{array}{l}\text { Partnerships for } \\
\text { the goals }\end{array}$ & 47 & $9,18 \%$ & 49 & $9,57 \%$ & 139 & $27,15 \%$ & 112 & $21,88 \%$ & 165 & $32,23 \%$ & 3,58 \\
\hline
\end{tabular}

Data of the Table 5 makes it obvious that at the first-place business should contribute to the achievement of "responsible consumption and production" (average score 4.23). The fact that this goal gained most attention is also confirmed by the findings of Kandler Rodríguez (2020 and Cai\&Choi (2020) claiming that this goal also gained most attention and is prioritized by companies. In authors opinion this is also due to growing debates over the consumer society in mass media and growing number of examples of minimalism in everyday life. "Partnership for the goals" gained least attention and importance but in authors opinion this is considered by most respondents to be reached on the state and international level.

The SDGs represent a real challenge to the worldwide community and a call for an urgent action on all levels. The main focus should be addressing all inequalities across the world with no exception. Successful implementation of these goals would require joint efforts of all stakeholders. Effectiveness of positive practices contributing to SDGs are already shown by large well-known companies in different countries. Numerous companies have included SDGs into their sustainability programs and strategies of future development. Latest research findings demonstrate that companies are nowadays focusing on the SDGs implementation being driven by ethical and social responsibility and initiated by stakeholders' concern. These developments were also confirmed by the present research, where stakeholders demonstrated high level of awareness of CSR also stating that company should provide information on sustainable development.

Current study focused on stakeholders' opinion on the SDG importance of embedding the SDGs into everyday business processes with the main task to arrange a survey among the customers of telecommunication companies. These companies were chosen due to their growing impact on every aspect of society and important role in everyday life and almost all Estonian people use their services being well aware of their activities and visit websites of these companies quite often. The task was reached by summarizing and analyzing findings of the survey.
Table 5

Embedding SDGs into business processes by telecommunications companies operating in Estonia Group 3 - Society (rated by Likert scale, 1- not important at all; 5very important)

Source: Authors'. 
The results revealed several SDGs as the top areas of contribution: SDG 12 „responsible consumption and production", SDG 15 "life on land", SDG 6 "clean water and sanitation" and SDG 4 "quality education". In authors opinion these results are highly influenced by the COVID -19 outbreak, which led to the transformation of human conscience and shifted the priorities by highlighting the importance of environmental health and long-lasting values like good health and education. The study also concludes that SDG related activities should be highly prioritized by companies and boosted by their business activities.

In general, it can be concluded that joint efforts are required to make Agenda 2030 a real action plan for everybody and contribute to the successful achievement of the SDGs.

These results give a good understanding of stakeholders' opinion on the importance of SDG achievement and a role of business community in this process. However, they should be treated with caution as the sample of the respondents is quite small and while the rate of response was quite high, still the results of the survey cannot be generalized. In future it may be useful to differentiate respondents according to age, social status, working experience etc. and arrange survey among different groups. The study also provides a good path for future research in this area as well as a guidance for companies' managers in preparing strategic plans for the companies and attracting potential investors.

Allen, C., Metternicht, G., \& Wiedmann, T. (2017). An iterative framework for national scenario modelling for the sustainable development goals (SDGs). Sustainable Development, 25(5), 372-385. https:// doi.org/10.1002/sd.1662

Allen, C., Reid, M., Thwaites, J., Glover, R., \& Kestin, T. (2020). Assessing national progress and priorities for the sustainable development goals (SDGs): Experience from Australia. Sustainability Science, 15(2), 521-538. https://doi.org/10.1007/s11625019-00711-x

Avrampou, A., Skouloudis, A., Iliopoulos, G., \& Khan, N. (2019). Advancing the sustainable development goals: Evidence from leading European banks. Sustainable Development, 27(4), 743-757. https://doi. org/10.1002/sd.1938

Bates, A. E., Primack, R. B., Moraga, P., \& Duarte, C. M. (2020). COVID-19 pandemic and associated lockdown as a "Global Human Confinement Experiment" to investigate biodiversity conservation. Biological conservation, 248, 108665. https://doi. org/10.1016/j.biocon.2020.108665

Breu, T., Bergöö, M., Ebneter, L., Pham-Truffert, M., Bieri, S., Messerli, P., . . B Bader, C. (2021). Where to begin? defining national strategies for implementing the 2030 agenda: The case of Switzerland. Sustainability Science, 16(1), 183-201. https://doi. org/10.1007/s11625-020-00856-0

Biermann, F., Kanie, N., \& Kim, R. E. (2017). Glob- al governance by goal-setting: The novel approach of the UN sustainable development goals. Current Opinion in Environmental Sustainability, 26-27, 2631. https://doi.org/10.1016/j.cosust.2017.01.010

Cai, Y. -., \& Choi, T. -. (2020). A united nations' sustainable development goals perspective for sustainable textile and apparel supply chain management. Transportation Research Part E: Logistics and Transportation Review, 141 https://doi.org/10.1016/j. tre.2020.102010

García-Sánchez, I. -., Rodríguez-Ariza, L., Aibar-Guzmán, B., \& Aibar-Guzmán, C. (2020). Do institutional investors drive corporate transparency regarding business contribution to the sustainable development goals? Business Strategy and the Environment, 29(5), 2019-2036. https://doi. org/10.1002/bse.2485

Hughes, B. B., \& Johnston, P. D. (2005). Sustainable futures: Policies for global development. Futures, 37(8), 813-831. https://doi.org/10.1016/j. futures.2005.01.017

Kandler Rodríguez, J. M. (2020). Exploring the applicability of sustainable development goals in Costa Rica: Case examples from mastatal and conchal. Worldwide Hospitality and Tourism Themes, https://doi.org/10.1108/WHATT-06-2020-0044

Khalid, A. M., Sharma, S., \& Dubey, A. K. (2020). Concerns of developing countries and the sustainable development goals: Case for India. Internation- 
al Journal of Sustainable Development and World Ecology, https://doi.org/10.1080/13504509.2020. 1795744

Kroll, C., Warchold, A., \& Pradhan, P. (2019). Sustainable development goals (SDGs): Are we successful in turning trade-offs into synergies? Palgrave Communications, 5(1) https://doi.org/10.1057/s41599019-0335-5

Kunčič, A. (2019). Prioritising the sustainable development goals using a network approach: Sdg linkages and groups. Teorija in Praksa, 56(3 Special Issue), 418-437. Retrieved from www.scopus.com

Manenti, R., Mori, E., Di Canio, V., Mercurio, S., Picone, M., Caffi, M., Brambilla, M., Ficetola, G. F., \& Rubolini, D. (2020). The good, the bad and the ugly of COVID-19 lockdown effects on wildlife conservation: Insights from the first European locked down country. Biological conservation, 249, 108728 https://doi.org/10.1016/j.biocon.2020.108728

Meyer, W. (2020). Evaluation of sustainable development goals between ambition and reality: How the agenda 2030 challenges the evaluation practice. [Die evaluation der sustainable development goals zwischen anspruch und wirklichkeit] Zeitschrift Fur Evaluation, 19(2), 221-238. https://doi.org/10.31244/ zfe.2020.02.02

Mio, C., Panfilo, S., \& Blundo, B. (2020). Sustainable development goals and the strategic role of business: A systematic literature review. Business Strategy and the Environment, 29(8), 3220-3245. https:// doi.org/10.1002/bse.2568

Milwood, P. (2020). Social responsibility and the SDGs: Vignettes of Caribbean tour operators. Worldwide Hospitality and Tourism Themes, 12(3), 275-292. https://doi.org/10.1108/ WHATT-02-2020-0005

Patchell, J., \& Hayter, R. (2021). The cloud's fearsome five renewable energy strategies: Coupling sustainable development goals with firm specific advantages. Journal of Cleaner Production, 288 https://doi.org/10.1016/j.jclepro.2020.125501

Ramos, C. M., \& Laurenti, R. (2020). Towards the agenda 2030: A quantitative analysis of synergies and trade-offs between the SDGs of Spain during 2000-2019. Sustainability (Switzerland), 12(24), 1-14. 6 https://doi.org/10.3390/su122410506

Santos, M. J., \& Silva Bastos, C. (2020). The adoption of sustainable development goals by large portuguese companies. Social Responsibility Journal, https://doi.org/10.1108/SRJ-07-2018-0184
Scharlemann, J. P. W., Brock, R. C., Balfour, N., Brown, C., Burgess, N. D., Guth, M. K., ... Kapos, V. (2020). Towards understanding interactions between sustainable development goals: The role of environment-human linkages. Sustainability Science, 15(6), 1573-1584. https://doi.org/10.1007/s11625-020-00799-6

Silva, S. (2021). Corporate contributions to the sustainable developmment goals: An empirical analysis informed by legitimacy theory. Journal of Cleaner Production, 292. https://doi.org/10.1016/j.jclepro.2021.125962

Sustainable Development Goals Knowledge Platform. Retrieved January 26, 2021, from https:// sustainabledevelopment.un.org/memberstates/ estonia\#: :text=The\%20SDGs\%20are\%20the\%20 basis,adopting\%20the\%20UN\%20Agenda\%202030.

Tremblay, D., Fortier, F., Boucher, J. -., Riffon, O., \& Villeneuve, C. (2020). Sustainable development goal interactions: An analysis based on the five pillars of the 2030 agenda. Sustainable Development, 28(6), 1584-1596. https://doi.org/10.1002/sd.2107

Tsalis, T. A., Malamateniou, K. E., Koulouriotis, D., \& Nikolaou, I. E. (2020). New challenges for corporate sustainability reporting: United nations' 2030 agenda for sustainable development and the sustainable development goals. Corporate Social Responsibility and Environmental Management, 27(4), 1617-1629. https://doi.org/10.1002/csr.1910

UNICEF (2020). Retrieved May 02, 2021, from https://www.unicef.org/mena/stories/cleaningand-hygiene-tips-help-keep-covid-19-virus-outyour-home.

Warchold, A., Pradhan, P., \& Kropp, J. P. (2020). Variations in sustainable development goal interactions: Population, regional, and income disaggregation. Sustainable Development, https://doi. org/10.1002/sd.2145

Xie, H., Wen, J., \& Choi, Y. (2021). How the SDGs are implemented in China--A comparative study based on the perspective of policy instruments. Journal of Cleaner Production, 291 https://doi.org/10.1016/j. jclepro.2021.125937

Zhang, J., Wang, S., Zhao, W., Liu, Y., \& Fu, B. (2019). Research progress on the interlinkages between the 17 sustainable development goals and their implication for domestic study. Shengtai Xuebao/ Acta Ecologica Sinica, 39(22), 8327-8337. https:// doi.org/10.5846/stxb201902200299

United Nations (2021). Retrieved February 16, 2021 , from https://www.un.org/en/ 
About the authors

\section{GURVITŠ-SUITS}

NATALIE ALEKSANDRA

$\mathrm{PhD}$.

Tallinn University of Technology

Fields of interests

Financial and non-financial reporting, Sustainable business development, SDG, PRME.

\section{Address}

Akadeemia tee 3, Tallin, 12618, Estonia,

+ 3726204007 ,

natalja.gurvits@ttu.ee

\section{LVOVA ANNA-LIIZA}

MAcc / Master of Arts in Social Sciences

Tallinn University of Technology

\section{Fields of interests}

Financial and non-financial reporting, Sustainable business development.

\section{Address}

Akadeemia tee 3, Tallin, 12618, Estonia, +37258132152,

annleelv@gmail.com 